\title{
REDD comes into fashion in Madagascar
}

\author{
Barry Ferguson
}

\section{ABSTRACT}

As the Copenhagen negotiations on the form of post Kyoto mechanisms to tackle climate change approach, firmly on the agenda are proposals to include Reduced Emissions from Deforestation and forest Degradation (REDD). REDD could potentially generate tens of millions of dollars annually for Madagascar, bringing a huge potential to deliver forest conservation and improved livelihoods for the rural Malagasy. Efforts are underway in Madagascar to access REDD finance through a national working group and implementation of five REDD pilot projects. Many areas where the lowering of rates of deforestation is hoped to take place are part of the new generation of protected areas following the 2003 Durban Declaration. These new protected areas are frequently based on federations or grouping of community managed forests, which the literature and experience has shown to be highly problematic and which are rarely fully operational. If REDD is to prove to be an effective conservation tool, as well as an equitable mechanism to promote rural development several issues need to be addressed: More resources allocated to provide direct incentives to communities and to build local management capacity within their forest management associations. More serious efforts are needed to increase forest plantations and to improve management of existing plantations and natural forests, so as to meet the forest product needs of the whole Malagasy population. Basic human rights to have secure tenure of ancestral forest lands, and to derive a decent living from these needs to be recognised and empowered. The risk of 'elite capture' of the revenues generated by REDD should be avoided by the establishment of a transparent and independent scrutiny facility. Finally, it is proposed that improved dialogue between the social critics of conservation in Madagascar and the conservation movement itself should be encouraged.

\section{RÉSUMÉ}

Alors que nous entamons les négociations post-Kyoto à Copenhague sur les mécanismes destinés à lutter contre le changement climatique, des propositions portant sur la Réduction des Émissions résultant du Déboisement et de la Dégradation forestière (REDD) sont nettement à I'ordre du jour. En ce qui concerne Madagascar, le programme REDD a la capacité de produire des dizaines de millions de dollars annuellement en permettant la conservation des forêts mais aussi l'amélioration du niveau de vie des populations rurales malgaches. Des efforts sont
School of International Development, University of East Anglia Norwich, Norfolk, NR4 7TJ, U. K. Phone: +44 (0) 2891815566 E-mail: ferguson.barry@gmail.com

actuellement consentis à Madagascar pour accéder au financement REDD à travers un groupe de travail national et aussi avec la mise en œuvre de cinq projets pilote. Les endroits dans lesquels un espoir est nourri pour baisser le taux de déboisement sont nombreux et ont tous été inclus dans ce qu'on appelle communément 'les nouvelles aires protégées' conformément à la Déclaration de Durban de 2003. Ces nouvelles aires protégées sont généralement basées sur des regroupements ou fédérations de communautés de base pour la gestion des forêts ; cependant ces groupements ont souvent été reconnues dans les écrits et sur le terrain comme étant pour le moins problématiques et rarement tout à fait opérationnels. Dans ce contexte, REDD pourrait s'avérer être un outil pertinent pour la protection de la nature ainsi qu'un mécanisme équitable pour favoriser le développement rural, sachant cependant que plusieurs aspects devront être appréhendés au préalable. II s'agira notamment d'allouer davantage de ressources pour attirer effectivement les communautés de base, et simultanément de mettre en place les moyens d'une gestion locale au sein de leurs associations destinées à gérer les ressources forestières. De plus amples efforts devront aussi être consentis pour étendre la superficie des plantations forestières et pour améliorer la gestion des plantations existantes et des forêts naturelles de manière à pouvoir satisfaire la demande en produits sylvicoles de l'ensemble de la population malgache. Parmi les droits fondamentaux, on retrouve le droit d'hériter de la forêt des ancêtres et la possibilité de pouvoir puiser en son sein les ressources vitales pour vivre avec dignité, qui sont des aspects qu'il faudra identifier et respecter. II existe toujours un risque de discrimination en favorisant une certaine élite avec les revenus produits par REDD, mais ce risque devrait être évité avec la mise en place de contrôles minutieux, transparents et indépendants. Finalement, il est proposé d'ouvrir le dialogue avec les critiques sociaux à Madagascar et d'encourager le mouvement de la protection de la nature proprement dit.

KEYWORDS: REDD, community forest management, human rights, PES, deforestation.

MOTS CLEF : REDD, gestion communautaire des forêts, droits de I'homme, PSE, déforestation.

\section{INTRODUCTION}

Madagascar is well known as a global biodiversity conservation priority, and since the early 1990s has often been at the forefront 


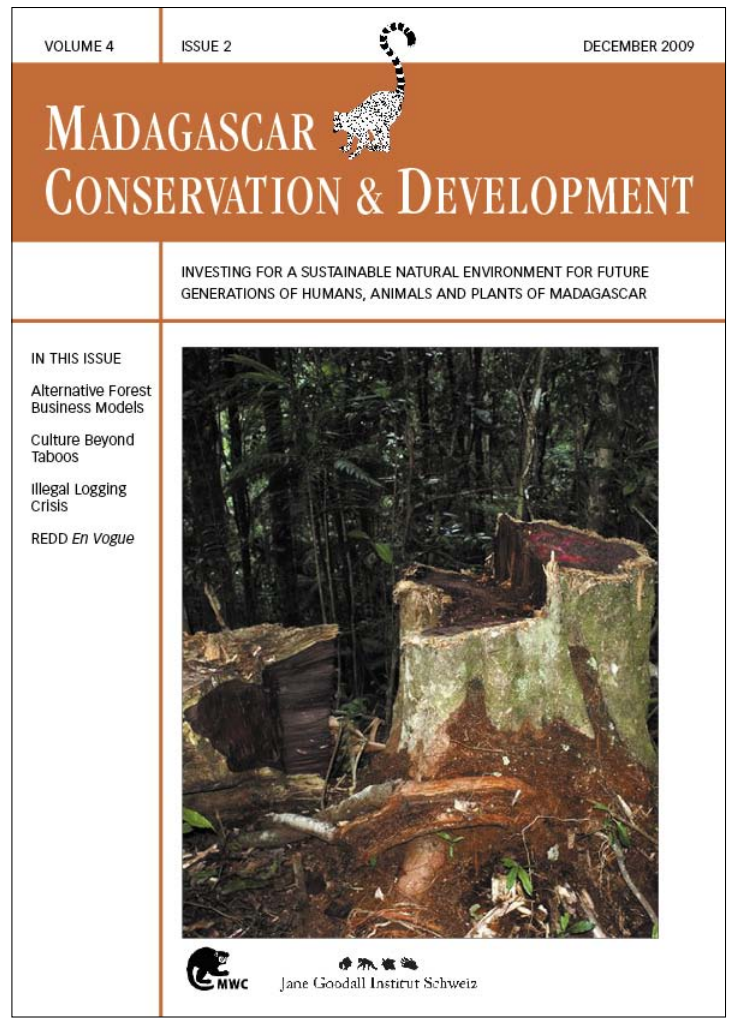

Madagascar Conservation \& Development is the journal of Madagascar Wildlife Conservation (MWC) and the Jane Goodall Institute (JGI Switzerland). It is produced in these institutions' own responsibility.

All the Issues and articles are freely available at http://www.mwc-info.net/en/services/journal.htm

Contact Journal MCD

info@journalmcd.net for general inquiries MCD funding@journalmcd.net for supporting the journal

Journal Madagascar Conservation \& Development Institute and Museum of Anthropology University of Zurich

Winterthurerstrasse 190

$\mathrm{CH}-8057$ Zurich, Switzerland

contact@mwc-info.net for general inquiries

Postfach 2701

CH-8021 Zürich, Switzerland

Logement 11, Cité Andohaniato

Antananarivo 101, Madagascar

info@janegoodall.ch for general inquiries JG

$2 \pi \approx$

Jane Goodall Institut Schweiz
Jane Goodall Institute Schweiz

Postfach 2807

8033 Zürich

switzerland 
of innovation in conservation policies in the developing world. Integrated Conservation and Development Projects (ICDPS) (Gezon 1997, Marcus 2001), Community Forest Management (CFM) (Bertrand and Weber 1995, Antona et al. 2004), Ecoregion Based Conservation (Cowles et al. 2001, Fenn 2003) and a new generation of community and co-managed protected areas (Raik 2007, Gardner et al. 2008) are among the initiatives which have been rolled out across Madagascar since the start of the National Environmental Action Plan (NEAP). Among the latest additions to the portfolio of conservation approaches in Madagascar is a system of Payments for Ecosystem Services (PES) designed to reduce the $\mathrm{CO}_{2}$ emissions produced by deforestation and forest degradation. Known as REDD (Reduced Emissions from Deforestation and forest Degradation), this form of PES is part of global efforts to include forest conservation in the post Kyoto mechanisms for tackling climate change. The basic premise of REDD is that countries which have high rates of deforestation and forest degradation, should be facilitated to access finance from carbon markets and trading schemes, in order to pay for the reductions of the rates of forest clearance and degradation which will result in lower carbon dioxide emissions (Ebeling and Yasué 2008, MEFT 2008, Angelsen 2008, Parker et al. 2009). In order to qualify, projects or national schemes would have to ensure, over periods of 30 years, that changes would not lead to 'leakage' of $\mathrm{CO}_{2}$ emitting activities outside the defined project/national boundary, that their interventions are leading to 'additional' reductions compared to what would already happen. Furthermore it must be demonstrated that reductions are 'permanent'. The issues of additionality and permanence are assessed partly through the establishment of agreed baseline information on what is happening already and by making projections of what is likely to happen with and without intervention. The actual carbon stocks held in the forests are also monitored to demonstrate the storage and sequestration realised. $\mathrm{CO}_{2}$ emissions reductions generated by sub-national REDD initiatives can already be traded on the voluntary carbon market after accreditation through voluntary standards (e.g., VCS 2007). The aspiration of many stakeholders at the outset of the COP15 talks in Copenhagen is to have REDD recognised by an international regulatory system which will be the successor to the Kyoto Protocol of the United Nations Framework Convention on Climate Change (UNFCCC). Such a post Kyoto mechanism will allow the trading of national level $\mathrm{CO}_{2}$ emission reductions through an internationally regulated market and will allow countries that reduce their emissions to generate revenues as a result. It is unclear if and how the sub-national voluntary agreements which exist already will integrate with such national level processes if REDD is included in the new system. Amid the frenzy and excitement about more funding for forest conservation and the increased opportunities to offset emissions, there are sceptics who do not agree with the basic concept of REDD, and others who highlight the inherent difficulties of such a scheme (for more information on this see Hall 2008, Bullock et al. 2009, Livengood and Dixon 2009, REDD Monitor 2009). Criticisms range from the simple fact that forests are not permanent installations, to the matter that 'leakage' of forest use outside sub-national project and state borders can occur and is difficult to monitor. Such leakage could mean that while particular projects and countries may be successful in reducing emissions, that the shifting of forest uses elsewhere would mean that global $\mathrm{CO}_{2}$ emissions would not actually be reduced. Also of concern to commentators is the risk of marginalising and impacting negatively of the livelihoods and rights of forest peoples (Rights and Resources Initiative 2008, Colchester 2009, Cotula and Mayers 2009). There are also groups lobbying to ensure that REDD does not allow the conversion of natural forests into plantations to be rewarded, and who wish for biodiversity conservation to be specifically addressed through a more nuanced REDD mechanism, currently being referred to as REDD+ (see Association for Tropical Biology and Conservation 2009, Grainger et al. 2009).

Through both, national and project level REDD processes Madagascar is once again at the forefront of innovation in conservation policies. Since 2008 a national working group (known as the CT-REDD) has been advancing proposals for REDD strategies in Madagascar and five sub-national REDD Pilot projects are now being implemented by international conservation NGOs in partnership with the Malagasy authorities (see Supplementary Material for more detail).

The five REDD Pilot Projects in Madagascar and their implementers:

- Makira - Makira Carbon Company (MCC) and Wildlife

Conservation Society (WCS);

- $\quad$ Ankeniheny to Zahamena Forest Corridor (CAZ)-

Conservation International;

- $\quad$ Fandriana to Vondrozo Forest Corridor (COFAV)-

Conservation International;

- Holistic Forest Conservation Programme (PHCF)-

WWF and Good Planet;

- FORECA - GTZ/Inter-cooperation.

Considering the existing rates of deforestation in Madagascar and projections of how much it may be possible to reduce these by, it has been estimated that the potential annual income from a REDD finance mechanism could be worth as much as US \$ 72-144 million to Madagascar (Hannah et al. 2008). Through the REDD initiatives underway in Madagascar, specialists are already developing models and methods to deal with the technical issues of measuring and monitoring reductions of deforestation and degradation (Martin et al. 2004a, b, Holmes et al. 2008, Pedroni 2008, Green Synergy 2009, WWF 2009). Three of the five sub-national REDD Pilot Projects (Makira, CAZ and COFAV) are being developed to provide site-based emissions reductions for sale, based on three of the largest new protected areas which have been established in the new Malagasy System of Protected Areas (SAPM). The WCS led Makira project is arguably the most advanced of the three and the Makira Carbon Company was launched in 2008 and is currently finalising accreditation through the Climate, Community and Biodiversity Alliance (CCBA) standards (CCBA 2005, 2008) in order to enter the voluntary carbon market. A fourth REDD Pilot, the Holistic Forest Conservation Programme (PHCF) implemented by WWF and Good Planet combines the development of technical and methodological expertise on deforestation and degradation monitoring with the establishment of over 500,000 hectares of new community managed protected areas as well as extensive habitat restoration. The PHCF is not currently preparing REDD credits for sale, as the WWF Green Carbon Standard, which would facilitate such transactions, is still under development. The fifth REDD Pilot is FORECA, which is implemented by GTZ and Inter-cooperation 
and is working in sites across Madagascar to resolve technical issues including the definition of forest, the monitoring of forest change and to deepen the understanding of socio-economic aspects of how the eventual REDD system may function. All five projects are contributing important lessons to the national level process of establishing REDD policies for Madagascar, through their representation on the CT-REDD and through their capacity building components.

\section{CHALLENGES FACING REDD: SOCIAL CONSIDERATIONS}

The prospect of accessing tens of millions of dollars annually for forest conservation in Madagascar is an exciting one for the conservation sector on the island, and certainly brings with it great potential to conserve forests and support forest peoples to improve their livelihoods. Many technical challenges such as dealing with additionality, permanence, leakage, monitoring, and forest definition need to be overcome before REDD finance will become a reality for Madagascar. However, this section will leave aside such 'technical issues' and aims to provide some preliminary reflections on the social considerations which will need to be addressed if REDD is to become an equitable and effective conservation and development tool in Madagascar.

There is no shortage of social critiques of the ethics, conception, design and implementation of forest conservation in Madagascar over the period of the NEAP (e.g., Walker 2001, Horning 2004, 2005, 2006, Kaufmann 2006, Pollini 2007, Corson 2008, Harper 2008, Keller 2008, 2009, Muttenzer 2008, Simsik 2008, Sodikoff 2008). While the studies behind these criticisms are often based on particular localities or organisations, they also provide insights relevant across Madagascar's forest conservation policies. Although they may not be specific to REDD, many of the social criticisms of conservation in Madagascar remain largely unresolved and will, unless they are properly dealt with, still act as blockages to achieving the positive outcomes, which it is hoped that REDD will bring. For the purposes of this paper, the following four social challenges are highlighted as being of particular significance for the future success of REDD in Madagascar:

MAKING THE BASIC BUILDING BLOCKS OF CONSERVATION

FUNCTION. The Durban Vision of 2003 has led to a massive expansion of terrestrial protected areas across Madagascar. Together the strict protected areas already in existence before 2003 and the new protected areas established since then now cover almost $60 \%$ of the remaining forests in Madagascar (see Supplementary Material for details of current forest management regimes). While the older generation of protected areas (National Parks, Special Reserves and Integral Nature Reserves) are typically strict in terms of forbidding most human use, the design of new protected areas is often based on the establishment of community managed forests using the Gestion Contractualisée des Forêts (GCF) or Gestion Locale Sécurisée (GELOSE) policies, which allow for certain permitted uses. These GCF/GELOSE forests typically have communities living within and close to the forests, and who use them for various aspects of their livelihoods. The literature tells us that of the hundreds of GCF/GELOSE contracts in existence across the island, most are not fully operational because communities and individuals often lack incentives and the capacity to implement the management activities which GCF and GELOSE require them to undertake (Casse 2007, Hockley and Andriamarovololona 2007, Montagne et al. 2007, Raik 2008). These community forestry contracts are the basic management units for many of the areas where deforestation reductions must occur to gain revenue from REDD, but they are currently not working. If REDD is to be successful in Madagascar it is necessary that significantly more resources are allocated to build the capacity of forest managing communities and to provide them with livelihood based incentives to allow them to stop deforestation without experiencing livelihood deterioration.

MEETING THE NEEDS OF MALAGASY FOREST USERS.

Most of the people of Madagascar depend on forest products (from plantations and natural forests) for cooking fuel, and many people also depend on forests to provide their construction materials (GISC 2009). People living closest to the forest also depend, to varying degrees, on forest products for food, medicine, livestock fodder and pasture. Also significant are those forest people who currently depend on clearing forest to establish new agricultural land. At present Madagascar's forests are being used faster than they are being replanted, restored and regenerated, leading to an annual rate of deforestation of $0.53 \%$ between 2000 and 2005 (MEFT/USAID/CI 2009). In order to meet the needs of a growing population, while aspiring to reduce deforestation and degradation for REDD, a combination of substantial new forest plantations, improved management of existing plantations and the sustainable exploitation and rehabilitation of natural forests will be necessary. In addition, rural farmers who currently depend on tavy/tetik ala/hatsake (slash and burn or shifting agriculture) will need to be provided with sustainable livelihood alternatives at a scale substantially greater than that is currently happening. It is recognised that mechanisms to make payments of REDD revenues directly to communities do not currently exist (Nayer 2009) and efforts to provide direct payments for ecosystem services have been directed towards community level projects in health, education and development. While general community development, improved healthcare and education are all very worthy activities in their own right, it has yet to be demonstrated that they are either suitable or adequate as a replacement for household food production based on slash and burn agriculture. It should be a priority in Madagascar to establish new mechanisms to ensure that individuals and households can directly receive revenues generated by REDD in order to compensate them for losses incurred from lowering deforestation and forest degradation.

ENSURING THAT HUMAN RIGHTS TO ANCESTRAL LAND AND LIVELIHOODS ARE RESPECTED AND THAT STAKEHOLDERS

UNDERSTAND REDD. It could legitimately be argued that it is a basic human right to be allowed to derive a living from one's own ancestral lands. In Madagascar there is currently a situation where the state rarely recognises either customary forms of tenure over the forest or the associated rights to use the forest for what are perceived locally to be legitimate livelihood purposes. While relative tenure security (SFR) is possible as part of community forestry policies (GOM 1998), it neither recognises individual ownership, nor has it been implemented very often because it is costly and time consuming (Razafindraibe et al. 2007). More recent land tenure reform (GOM 2006) does have the potential to recognise individual customary tenure, but the rapid expansion of protected areas (which disqualifies land from such private tenure recognition) means that most remaining forests are likely to be excluded from such recognition. It is suggested that for REDD to produce an equitable situation to 
take account of the human rights of the rural Malagasy, it will be necessary to recognise customary forms of tenure over agricultural and forest lands and to adopt broader consideration of both the concept of 'forest dweller' (World Resources Institute 2009) and that of 'indigenous peoples'. Both, the International Labour Organisation (ILO) Convention 169 (1989) and the 2007 United Nations Declaration on the Rights of Indigenous Peoples (UNDRIP) provide a legal basis for these issues to be further explored (Lawlor and Huberman 2009).

AVOIDING EXCESSIVE ELITE CAPTURE. International conservation activities often provide an opportunity for various kinds of 'elites' to gain access to a large share of the resources made available by donors. This dynamic plays out at all scales, from the elites within villages who may dominate forest user groups and capture resources, to government agencies who receive substantial budget support from international donors. It is also significant among international consultants and companies whose expertise is used in project design, management and monitoring, and which is costly. International conservation NGOs also lobby for and receive a great deal of the financial resources available for conservation, in order to maintain the momentum of operations in their organisations (Duffy 2006a, b, Brockington et al. 2008, Corson 2008, Brockington 2009). Once the services and operations of central and regional government agencies, NGOs and consultants have been paid for there are usually very meagre resources remaining for use at the community level. At the international level the carbon-trading sector is also already awash with all manner of entrepreneurs operating on the interface between the private, state and voluntary sectors. With these dynamics in mind, it will be important to ensure that any REDD mechanism in Madagascar can maximise the benefits for local forest users on whose ancestral lands grow the forests which both REDD revenue and local livelihoods will depend upon. It will be essential to have detailed, independent and transparent scrutiny across scales regarding how equitable the distribution of the revenue generated by REDD will be. Of course, consultants, government agencies, NGOs and forest user groups will inevitably all have a role in the future REDD mechanisms, but the local forest users themselves must not be neglected by the conservation movement as they often have been in the past.

\section{CONCLUSION}

This paper has strived to provide a very brief overview of the concept of REDD and what is currently underway in this field in Madagascar. It has also identified some of the social challenges which will need to be addressed in order to make REDD equitable for the Malagasy, effective for forest conservation and to result in $\mathrm{CO}_{2}$ emissions reductions in order to contribute to climate change. Hopefully this will spur more engaged and inclusive discussions in the near future, particularly between social critics of conservation and the conservation movement itself, as this is something which has been somewhat lacking to date (Kaaristo 2008, Ratsimbazafy et al. 2008). Supplementary Material is provided in the form of a report ('REDD in Madagascar: An Overview of Progress') presenting more detailed background information and insights on the issues around REDD in Madagascar.

\section{ACKNOWLEDGEMENTS}

I would like to thank the representatives from the conservation organisations in Madagascar who provided information which contributed to this paper: Romuald Vaudry, James MacKinnon, Christian Burren, Richard Lewis, Martin Nicoll,Flavien Rebara, Malika Virah-Sawmy, Bruno Ramamonjisoa, Vololona Rasoarimanana, Monique Andriamananoro, Haniela Randrianjafison, Joana Borges Coutinho and Chris Birkinshaw. Thanks also to Frank Muttenzer, Jacques Pollini, Johannes Ebeling and two anonymous reviewers whose contributions provided corrections, improved my thinking on the subject and enhanced the text considerably. Time spent on the preparation of this paper was partly supported by a NERC/ ESRC Doctoral Studentship to the author.

\section{REFERENCES}

Angelsen, A. 2008. Moving Ahead With REDD: Issues Options and Implications. Center for International Forestry Research, Bogor, Indonesia.

Antona, M., Biénabe, E. M., Salles, J-M., Péchard, G., Aubert, S. and Ratsimbarison, R. 2004. Rights transfers in Madagascar biodiversity policies: Achievements and significance. Environment and Development Economics 9: 825-847. (doi:10.1017/S1355770X04001640)

Association for Tropical Biology and Conservation and the Society for Tropical Ecology, 2009. The Marburg Declaration, Marburg Germany, 26-29 July 2009. <http://www.atbio.org/> accessed 15 October 2009.

Bertrand, A. and Weber, J. 1995. From State to local Commons in Madagascar: A National policy for Local Management of Renewable resources, Paper presented to the Fifth Common Property Conference 'Reinventing the Commons' 24-28 May, Bodo, Norway. IASCP.

Brockington, D., Duffy, R. and Igoe, J. 2008. Nature Unbound: Conservation, Capitalism and the Future of Protected Areas. Earthscan, London.

Brockington, D. 2009. Celebrity and the Environment: Fame, Wealth and Power in Conservation. Zed Books, London.

Bullock, S., Childs, M. and Picken, T. 2009. A Dangerous Distraction: Why Offsetting is Failing the Climate and People, Friends of the Earth.

Casse, T. 2007. GELOSE - failure or success? Paper presented at the Conference - Society, natural Resources and Development in Madagascar: Recent Contributions by the Research Community, University of East Anglia, Norwich. 20 March 2007.

Climate, Community and Biodiversity Alliance. 2005. Climate, Community and Biodiversity Project Design Standards (First Edition). Washington D. C. Available at <www. climate-standards.org $>$.

Climate, Community and Biodiversity Alliance, 2008. Climate, Community and Biodiversity Project Design Standards Draft Second Edition Version 1.0. Arlington, Virginia. Available at <www.climate-standards.org $>$.

Colchester, M. 2009. Safeguarding rights in the FCPF. Presentation by the Forest Peoples Programme and Rights \& Resources Initiative at the Chatham House Dialogue on Forests, Governance \& Climate Change. Royal Society, London. 8 July 2009.

Corson, C. A. 2008. Mapping the Development Machine: The US Agency for International Development's Biodiversity Conservation Agenda in Madagascar. Unpub. Ph.D. Thesis, University of California, Berkeley.

Cotula, L. and Mayers, J. 2009. Tenure in REDD: Start-point or afterthought? Natural Resource Issues No. 15. International Institute for Environment and Development, London.

Cowles, P. D., Rakotoarisoa, S., Rasolonirinamanana, H. and Rasoarimanana, V. 2001. Facilitation, participation, and learning in an ecoregionbased planning process: The case of AGERAS in Toliara, Madagascar. In: Biological Diversity: Balancing Interests Through Adaptive Collaborative Management. L. E. Buck, C. C. Geisler, J. Schelhas and E. Wollenberg (eds), pp 407-422. CRC Press LLC, Boca Ranton, Florida.

Duffy, R. 2006a. Global environmental governance and the politics of ecotourism in Madagascar. Journal of Ecotourism 5, 1-2: 128-144. (doi:10.1080/14724040608668443)

Duffy, R. 2006b. NGOs and governance states: The impact of transnational environmental management networks in Madagascar. Environmental Politics 15, 5: 731-749. (doi:10.1080/09644010600937173)

Ebeling, J. and Yasué, M. 2008. Generating carbon finance through avoided deforestation and its potential to create climatic, conservation and human development benefits. Philosophical Transactions of the Royal Society B 363,1498:1917-1924. (doi:10.1098/rstb.2007.0029) 
Gardner, C. J., Ferguson, B., Rebara, F. and Ratsifandrihamanana, A. N. 2008. Integrating traditional values and management regimes into Madagascar's expanded protected area system: The case of Ankodida. In: Values of Protected Landscapes and Seascapes: Volume 2 Protected Landscapes and Cultural and Spiritual Values. J.-M. Mallarach (ed.), pp 92-103. IUCN World Commission on Protected Areas.

Gezon, L. 1997. Institutional structure and the effectiveness of integrated conservation and development projects: Case study from Madagascar. Human Organization 56, 4: 462-470.

Fenn, M. D. 2003. The spiny forest ecoregion. In: The Natural History of Madagascar. S. M. Goodman, and J. P. Benstead (eds.), pp 1525-1530. The University of Chicago Press.

GISC, 2009. Etude sur la Production et la Consommation en Produits Forestiers Ligneux à Madagascar, Version actualisée 2009, Report to IRG and USAID Madagascar.

GOM, 1998, Décret n 98610 sur la sécurisation foncière relative. Government of Madagascar.

GOM 2006 LOI N²006-031 DU 24 NOVEMBRE 2006 Fixant le régime juridique de la propriété foncière privée non-titrée. Government of Madagascar

Grainger, A., Boucher, D. H., Frumhoff, P. C., Laurance, W. F., Lovejoy, T. McNeely, J., Niekisch, M., Raven, P., Sodhi, N. S., Venter, O. and Pimm, S. L. 2009. Biodiversity and REDD at Copenhagen, Current Biology 19, 21: R974-976. (doi:10.1016/j.cub.2009.10.001)

Green Synergy. 2009. Réduction des émissions de GES dues au déboisement et à la dégradation des forêts à Madagascar : Etat des lieux et expériences en cours. Unpub. Report to the Madagascar REDD Technical Committee.

Hall, R. 2008. REDD Myths: A critical review of proposed mechanisms to reduce emissions from deforestation and degradation in developing countries, Friends of the Earth International Issue: 114

Hannah, L., Radhika, D., Lowry II, P. P., Andelman, S., Andrianarisata, M., Andriamaro, L., Cameron, A., Hijmans, R., Kremen, C., MacKinnon, J., Randrianasolo, H. H., Andriambololonera, S., Razafimpahanana, A. Randriamahazo, H., Randrianarisoa, J., Razafinjatovo, P., Raxworthy, C. Schatz, G. E., Tadross, M. and Wilmé, L. 2008. Climate change adaptation for conservation in Madagascar. Biology Letters 4, 5: 590-594. (doi:10.1098/rsbl.2008.0270)

Harper, J. 2008. The environment of environmentalism: Turning the ethnographic lense on a conservation project. In: Greening the Great Red Island: Madagascar in Nature and Culture. J. C. Kaufmann (ed.), pp 241-274. Africa Institute of South Africa.

Hockley, N. J. and Andriamarovololona, M. M. 2007. The economics of community forest management in Madagascar: Is there a free lunch? USAID Antananarivo.

Holmes, C., Ingram, J. C., Meyers, D., Crowley, H. and Victurine, R. 2008. Forest Carbon Financing for Biodiversity Conservation, Climate Change Mitigation and Improved Livelihoods: the Makira Forest Protected Area, Madagascar, Wildlife Conservation Society Report to USAID, August.

Horning, N. R. 2004. The Limits of Rules: When Rules Promote Forest Conservation and When they do not - Insights from Bara Country, Madagascar. Unpub. Ph. D. Thesis, Cornell University.

Horning, N. R. 2005. The cost of ignoring rules: Forest conservation and rural livelihood outcomes in Madagascar. Forests, Trees and Livelihoods 15, 2:149-166.

Horning, N. R. 2006. Strong Support for Weak Performance: State and Donors' Mutual Dependence in Madagascar, Paper Presented at the 11th Biannual meeting of the International Association for the Study of Common Property, Bali, Indonesia 19-23 June 2006.

Kaarista, M. 2008. The reluctant anthropologist: An interview with Maurice Bloch. <www.eurozine.com/articles/2008-02-28-bloch-en.html> accessed 20 November 2009.

Kaufmann, J. C. 2006. The sad opaqueness of the environmental crisis in Madagascar. Conservation and Society 4, 2: 179-193.

Keller, E. 2008. The banana plant and the moon: Conservation and the Malagasy ethos of life in Masoala, Madagascar. American Ethnologist 35, 4: 650-664. (doi:10.1111/j.1548-1425.2008.00103.x)
Keller, E. 2009. Who are "They"? Local understandings of NGO and state power in Masoala, Madagascar, Tsantsa 14: 11-20.

Lawlor, K. and Huberman, D. 2009. Reduced emissions from deforestation and forest degradation (REDD) and human rights, In Rights-based approaches: Exploring issues and opportunities for conservation, J. Campese, T. Sunderland, T. Greiber and G. Oviedo (eds.), pp 269-286. CIFOR and IUCN, Bogor, Indonesia.

Livengood, E. and Dixon, A. 2009. REDD and the effort to limit global warming to $2^{\circ} \mathrm{C}$ : Implications for Including REDD Credits in the International Carbon Market, Report by KEA3 Limited for Greenpeace International.

Marcus, R. R. 2001. Seeing the forest for the trees: Integrated conservation and development projects and local perceptions of conservation in Madagascar. Human Ecology 29, 4: 381-397. (doi: 10.1023/ A:1013189720278

Martin, N., Shoch, D., Pearson, T., Dushku, A. and Grimland, S. 2004a. Measurement and Monitoring Plan for the Andasibe-Mantadia Corridor Restoration and Conservation Carbon Project Madagascar, Report by Winrock International to Conservation International - Center for Environmental Leadership in Business.

Martin, N., Shoch. D., Pearson, T., Dushku, A. and Brown, S. 2004b. Feasibility Study for Avoided Deforestation Project in the Makira Region of Madagascar, Report by Winrock International to Conservation International - Center for Environmental Leadership in Business.

MEFT, 2008. Climate Change Solutions in Madagascar: The Role of Forests, Repoblikan'I Madigasikara, Ministry of Environment, Forests and Tourism.

MEFT, USAID \& Cl. 2009. Evolution de la couverture des forêts naturelles à Madagascar 1990-2000-2005.

Montagne, P., Razanamaharo, Z. \& Cooke, A. 2007. Tanteza: Le Transfert de Gestion à Madagascar, Dix Ans d'Efforts. CIRAD and RESOLVE Conseil, Madagascar.

Muttenzer, F. 2008. Integrated fortress conservation in the buffer zone of Ankarafantsika National Park: Malagasy narratives of conservation, participation and livelihoods. In: People, Protected Areas and Global Change: Participatory Conservation in Latin America, Africa, Asia and Europe. Perspectives of the Swiss National Centre of Competence in Research (NCCR) North-South, M. Galvin and T. Haller (eds.), pp 253286. University of Bern, Vol.3. Geographica Bernesia, Bern.

Nayer, A. 2009 Carbon trading: How to save a forest. Nature 462: 2629.(doi:10.1038/462026a)

Parker, C., Mitchell, A., Trivedi, M. and Mardas N. 2009. The Little REDD+ Book: An Updated Guide to Governmental and Non-Governmental Proposals for Reducing Emissions From Deforestation and Degradation, Global Canopy Programme, Oxford.

Pedroni, L. 2008. Methodology for Estimating Reductions of GHG Emissions from Mosiac deforestation, RED-NM-001 4 July. BioCarbon Fund.

Pollini, J. 2007. Slash and Burn Cultivation and Deforestation in the Malagasy Rain Forests: representations and Realities, Unpub. Ph. D. Thesis, Cornell University.

Raik, D. B. 2007. Forest management in Madagascar: An historical overview. Madagascar Conservation \& Development 2: 5-10.

Raik, D. B. 2008. Governance in Community-Based Forest Management: The Case of Madagascar, Unpub. Ph. D. Thesis, Cornell University.

Ratsimbazafy, J, Rakotoniaina, L. J. and Durbin, J. 2008. Cultural anthropologists and conservationists: Can we learn from each other to conserve the diversity of Malagasy species and culture? In: Greening the Great Red Island: Madagascar in Nature and Culture. J. C. Kaufmann (ed.), pp 301-315. Africa Institute of South Africa.

Razafindraibe, R., Andriambolanoro, D. and Rakotondrasata, M., 2007. Foncier et transfert de gestion : Ia SFR. In Tanteza: Le Transfert de Gestion à Madagascar. Dix Ans d'Efforts. P. Montagne , Z. Razanamaharo \& A. Cooke (eds.), pp. 105-110. CIRAD and RESOLVE Conseil, Madagascar.

REDD Monitor, 2009. REDD: An Introduction. <www.redd-monitor.org/reddan-introduction> accessed 20 November 2009.

Rights and Resources Initiative, 2008. Seeing People Through The Trees: Scaling Up Efforts to Advance Rights and Address Poverty, Conflict and Climate Change. Washington DC: RRI. 
Simsik, M. 2008. The Roles of power and conventional wisdom in biodiversity loss on the Malagasy Highlands. In: Greening the Great Red Island: Madagascar in Nature and Culture. J. C. Kaufmann (ed.), pp 137-156. Africa Institute of South Africa.

Sodikoff, G. 2008. Forest conservation and low wage labour. In: Greening the Great Red Island: Madagascar in Nature and Culture. J. C. Kaufmann (ed.), pp 69-89. Africa Institute of South Africa.

VCS, 2007, Voluntary Carbon Standard: Guidance for Agriculture, Forestry and Other Land Use Projects, $19^{\text {th }}$ November.

Walker, W. M. 2001. Defending the Environment, Conserving Social Life : Global Visions and Local Values in Southern Madagascar, PhD Dissertation, John Hopkins University.

World Resources Institute. 2009. Governance Analysis of FCPF R-PIN Documents, Washington DC.

WWF (World Wide Fund for Nature). 2009. Description of the Holistic Forest Conservation Project. <www.panda.org/fr/wwf_action_zones/madagascar_nature/programme_holistique/> accessed 20 November 2009.

\section{SUPPLEMENTARY MATERIAL.}

AVAILABLE ONLINE ONLY:

Report titled (REDD in Madagascar: An Overview of Progress.) prepared by Barry Ferguson, 5 November 2009, pp 46. 